\title{
IMPACT OF FOLK DANCE ON PHYSICAL CONDITIONING OF YOUNGER SCHOOL-AGE CHILDREN
}

\author{
Uǵis Ciematnieks \\ Rīga Stradin̄š University, Latvia \\ Aija Gulbe \\ Rīga Stradiṇš University, Latvia
}

\begin{abstract}
Children develop a variety of skills and knowledge from childhood, including physical activity habits that persist throughout their lives. Insufficient physical activity rates around the world are high and continue to increase (Latvian ministry of health, 2017). Dancing is one of the kinds of physical activity that can deliver benefits to health throughout life, even at the amateur level. Yet, it isn't quite clear yet whether dance intervention is as effective to health as other physical activities. (Yan, Cobley, \& Chan, 2018). The research question is - is it possible to increase general conditioning with folk dance classes besides a school activities? The aim of the study: explore the impact of folk dances on the children's body mass index and physical conditioning at a younger school age, compared with children engaged in other out of school physical activities and children not engaged in out of school physical activities. The study involved 117 children in age 9 -11 divided into three groups - going for folk dances after school, some kind of sport after school and without regular physical activity after school. The assessment of children's physical conditioning by the Eurofit tests showed a tendency that in average children's physical conditioning rates were "low" or "below average" no matter in which group they are. For children who do afterschool activity as folk dance, BMI is statistically equivalent to those children who are going for other physical activities and children who are not engaged in any afterschool physical activity. The physical conditioning rates for all three groups are statistically equivalent in the tests: standing broad jump, bent arm hang, shuttle run $5 \times 10 \mathrm{~m}$, while the test sit-ups the children lack of afterschool physical activity, average the result was one level lower than in the other groups. The main conclusion is, that volume of folk dance as afterschool physical activities is not enough to make significant difference of average physical conditioning level of children.
\end{abstract}

Keywords: children, conditioning, Eurofit tests, folk dance.

\section{Introduction}

Physical activity has a positive impact on the normal growth, mental development and well-being of the child. Dancing is one of the kinds of physical activity that can deliver benefits to health throughout life, even at the amateur level. Yet, it isn't quite clear yet whether dance intervention is as effective to 
health as other physical activities. (Yan, Cobley, \& Chan, 2018). Insufficient physical activity rates around the world are high and continue to grow. To maintain health, children should be physically active every day for at least 60 minutes. Physical activities longer than 60 minutes each day will bring additional health benefits (Latvian ministry of health, 2017).

According to data from the Ministry of Education and Science, in Riga in summer 2020, a festival of XII Latvian schools' youth songs and dances will take place, which is an acknowledgment that the ancient Latvian traditions of singing, dancing and music are continued and held in honor (National Education Content Centre, 2019). This event requires increased attention and endurance from children as physical load, so children should be generally physically well developed and in good health. As part of the study, we chose to study BMI and fitness rates for children of the youngest school age who are engaged in folk dances, and we would also like to see if these children body mass index (BMI) and physical fitness rates are equivalent to those of children engaged in other structured out-of-school physical activities and for children not engaged in structured out-of-school physical activities. It is therefore important to determine the children BMI and physical fitness indicators in this age, by measuring the anthropomorphic parameters of children and testing the physical fitness with Eurofit tests.

The purpose of the study: Explore the impact of folk dances on the BMI and physical conditioning of children of the youngest school age, comparing these indicators to children engaged in other structured afterschool physical activities and those who do not engage in afterschool physical activities.

Methods: Information questionnaires on general physical activity habits for children of the youngest school age of the educational institution; measurements of children anthropometric parameters and the calculation of the body mass index; four Eurofit tests for the physical conditioning.

The research was carried out at the one of Riga Elementary School. According to the research tasks, children were given questionnaires about general physical activity habits, the anthropometric parameters were measured for body mass index, and four Eurofit physical conditioning tests were performed in the gym with the help of physical education teachers.

Microsoft Excel and SPSS (Statistical Package for the Social Science) software were used for processing and analyzing the obtained data, which determined descriptive statistical elements - modality, median, means, standard deviation, and analyzed the obtained data with Chi-square or Fisher test, according to conditions. 


\section{Literature review}

Dance is a form of art, a form of human self-expression, communication and cognition of the world, which uses rhythmic, structured or improvised body movements within a given time and space frame (Bālina, 2019). Dance is based on the ancient lifestyle and traditions of the nation. Folk dance events are inherited from previous generations. The construction of these dances is simple and accessible to a large population, therefore sometimes the author of the dance is unknown. Folk dance is the creator of every nation's identity. Until the middle of 20th century, the term "folk dance" was used without any scientific discussion of its content. The study of folk dance began with the arrival of diverse dance styles and genres in European culture in middle of the 20th century (Spalva, 2019). To be able to dance requires a variety of movements, so dance can be considered as one of the forms of physical activity that promotes:

- health;

- development of general conditioning;

- increases bone density;

- $\quad$ develops muscles, flexibility, and balance;

- improves cognitive function and spatial awareness;

- $\quad$ reduces stress;

- $\quad$ reduces psychosomatic symptoms in children.

Dance interventions have the potential to reduce children's body mass index (BMI), body fat, blood pressure, thereby improving quality of life. (Schroeder, Ratcliffe, Perez, Earley, Bowman, \& Lipman, 2017; Kelli et al., 2015).

One of the most important factors of the overall health of children and adolescents that improves children's health and fitness is regular moderate or high intensity physical activity (Priedīte, Sauka, Kalniṇa, \& Lāriņš, 2015).

Participating in physical activity provides children with immediate social, mental and physical benefits, such as reducing symptoms of depression, improving academic and cognitive performance, promoting healthy bone structure, muscle growth and the development of important systems of the body, especially cardiovascular and pulmonary system by improving physical conditioning, muscle strength and preventing childhood obesity (Adams, Veitch, \& Barnett 2018).

It is necessary to include structured specific physical activities in the overall plan to promote comprehensive physical and mental development (Kalnina, 2011). In order for physical activity to help in maintaining or improvement of health, it is necessary for it to become a daily habit. There is guidelines of the minimum physical activity recommended. In Latvia, for children and adolescents aged 5-17 have been accepted to use the minimum physical activity recommended 
by the World Health Organization (WHO, 2011) - 60 minutes of average to high intensity physical activity every day. Predominantly aerobic physical activities, supplemented by high-intensity activities for the strengthening of bone and muscle at least 3 times a week; in order to ensure optimal health for children, a daily level of physical activity is required for which is required approximately 6$8 \mathrm{kcal} / \mathrm{kg} /$ day (Jansone, Fernāte, \& Bula-Biteniece, 2016).

Recently, children have been replacing their physical activity with activities related to modern technology - television, computer, smartphone, tablet and the like. Therefore, it is important to reduce the daily amount of time children spend sedentary (Priedīte, Sauka, Kalniņa, \& Lāriņšs, 2015).

A study of Latvian schoolchildren's health habits found that only $22 \%$ of boys and $15.3 \%$ of girls had sufficient physical activity (at least 60 minutes daily). Compared to study of 2005/2006 school year, there was a trend towards a decrease in overall physical activity. Since 2006, the number of boys who have sufficient physical activity has fallen by $5.6 \%$, while that of girls by $4.4 \%$ (Pudule, Velika, Grīnberga, Gobina, \& Villeruša, 2015).

As children spend more and more time sedentary, the number of overweight and obese children increases. Over the past decades, childhood obesity has grown rapidly worldwide and is described as a global epidemic (Priedīte, Sauka, Kalniņa, \& Lāriņš, 2015; Cunningham, Datar, Narayan, \& Kramer, 2017).

In order to prevent obesity, the body must strike a balance between the nutrients taken and the energy consumed. Adjustment of nutrient intake is helped by a balanced diet, while consumption - by a physical load (Rožkalne, 2009).

Physical exercise is used as an important instrument for preventing and treating obesity by developing motor abilities that contribute positively to body composition, metabolic activity and reduce balance disorders associated with overweight (Paes, Marins, \& Andreazzi, 2015).

\section{Methodology}

The study involved children of the youngest school age who have received parental consent to participate in the study; from classes 3-4, aged 9-11; children were divided into three groups - regularly folk dance activities and children engaged in other structured afterschool physical activities and children not engaged in structured afterschool physical activities. The children measured for anthropometric data and calculated the body mass index, they were required to pass four Eurofit motor abilities tests.

Body weight and height were determined in the medical staff office of the school, using the Wunder unit ( $\max 150 \mathrm{~kg}, \mathrm{e}=100 \mathrm{~g}$ ) and the stadiometer-height measuring tape attached to them. The body weight index was determined, calculated by the formula $=$ body weight $(\mathrm{kg}) \div$ height $(\mathrm{m} 2)$. 
During sports classes, with the help of sports teachers, children have to complete 4 Eurofit fitness tests - standing broad jump, bent arm hang, sit-ups, shuttle run 5x10m. Microsoft Excel and SPSS spreadsheet applications have been used for data processing, using descriptive statistics packet: an arithmetic mean, mode, median and standard deviation, and a comparison of two qualitative indicators (group membership and character membership) using the Chi-Square Test or Fisher's test according to the conditions.

\section{Research results}

The study involved 117 children, of whom 53 (45\%) were girls, 13 girls aged 9, 26 girls at age of 10, 14 girls at age of 11. From all the children 64 (55\%) were boys, 17 boys at age of 9,30 boys at age of 10, 17 boys was 11 years old. During the study, children of the youngest school age had to fill out questionnaires about general physical activity habits. One of the questions was whether a child is engaged in any afterschool physical activity, 100 children noted "yes" that they were doing, 17 children noted "no". The next question was to find out what physical activity the child was doing afterschool. From all children 36 (31\%) was going for folk dance afterschool activities, but remaining 64 (55\%) children were going for other afterschool activities, but 17 (14\%) of all the children was not going for any afterschool physical activity. Also, we included a question of daily duration of activities. For children attending folk dance the duration of one physical activity is on average 61,42 \pm SD39,66 minutes, ranging from 40 to 150 minutes; for children who are going for other structured physical activities, the duration of one activity is on average $61,98 \pm$ SD39,80 minutes, between 40 and 180 minutes. A body weight index was calculated for all the children, comparing these data between groups with the Fisher test (cross-population comparison test), resulted in $\mathrm{p}=0.102(\mathrm{p}>0.05)$, so it can be concluded that in all 3 groups BMI scores are equivalent and there are no statistically significant differences between groups (table 1).

Table 1 Assessment of children's BMI, number in each group

\begin{tabular}{lccccc}
\hline $\begin{array}{l}\text { Classification of } \\
\text { children in groups }\end{array}$ & Underweight 2 & Underweight & $\begin{array}{c}\text { Normal } \\
\text { weight }\end{array}$ & Pre-obesity & Obesity \\
\hline Folk dance & 1 & 1 & 26 & 5 & 3 \\
\hline $\begin{array}{l}\text { Afterschool physical } \\
\text { activities }\end{array}$ & 0 & 0 & 39 & 8 & 17 \\
\hline $\begin{array}{l}\text { Without afterschool } \\
\text { activities }\end{array}$ & 0 & 0 & 13 & 0 & 4 \\
\hline
\end{tabular}

$P$ value -0.102 if $p \geq 0.05$, the difference between the groups is not statistically significant.

Fisher's direct test has been used. $n=117$ 
Ciematnieks \&Gulbe, 2020. Impact of Folk Dance on Physical Conditioning of Younger School-Age Children

In the Eurofit test "standing broad jump" analyzing the results between the groups using the Fisher direct test, we obtained $p=0.103$, which shows that there are no statistically significant differences between the groups. Thus, in this test, $63 \%$ of children tend to get "low", "below average", "average" results, but only $37 \%$ "above average" and "high" results. The results can be seen in Table 2.

Table 2 Standing broad jump, number at each level

\begin{tabular}{lccccc}
\hline $\begin{array}{l}\text { Classification of } \\
\text { children in groups }\end{array}$ & High & $\begin{array}{c}\text { Above } \\
\text { average }\end{array}$ & Average & $\begin{array}{c}\text { Below } \\
\text { average }\end{array}$ & Low \\
\hline Folk dance & 5 & 3 & 13 & 10 & 5 \\
\hline $\begin{array}{l}\text { Afterschool physical } \\
\text { activities }\end{array}$ & 17 & 12 & 8 & 13 & 14 \\
\hline $\begin{array}{l}\text { Without afterschool } \\
\text { activities }\end{array}$ & 3 & 3 & 2 & 3 & 6 \\
\hline
\end{tabular}

$P$ value -0.103 if $p \geq 0.05$, the difference between the groups is not statistically significant.

Fisher's direct test has been used. $n=117$

The results of the "bent arm hang" test were also analyzed, the Fisher direct test shows $p=0,373$, so it can be concluded that there are no statistically significant differences between the groups. Of all children, 63\% tend to get "low," "below average," "average” but 37\% "above average" and "high" results. Test results in Table 3.

Table 3 Bent arm hang, number at each level

\begin{tabular}{lccccc}
\hline $\begin{array}{l}\text { Classification of } \\
\text { children } \\
\text { in groups }\end{array}$ & High & $\begin{array}{l}\text { Above } \\
\text { average }\end{array}$ & Average & $\begin{array}{l}\text { Below } \\
\text { average }\end{array}$ & Low \\
\hline Folk dance & 7 & 9 & 6 & 7 & 7 \\
\hline $\begin{array}{l}\text { Afterschool physical } \\
\text { activities }\end{array}$ & 13 & 6 & 12 & 19 & 14 \\
\hline $\begin{array}{l}\text { Without afterschool } \\
\text { activities }\end{array}$ & 2 & 6 & 2 & 3 & 4 \\
\hline $\begin{array}{l}P \text { value }-0.373, \text { if } p \geq 0.05, \text { the difference between the groups is not statistically significant. } \\
\text { Fisher's direct test has been } \text { used. } n=117\end{array}$
\end{tabular}

Analyzing the results of the "shuttle run" test, we see that folk dance participants tend to get "below average" and "low" results for $100 \%$ of children (table 4). 
SOCIETY. INTEGRATION. EDUCATION

Proceedings of the International Scientific Conference. Volume VI, May $22^{\text {th }}-23^{\text {th }}, 2020.133-141$

Table 4 Shuttle run 5x10m, number at each level

\begin{tabular}{lccccc}
\hline $\begin{array}{l}\text { Classification of } \\
\text { children in groups }\end{array}$ & High & $\begin{array}{l}\text { Above } \\
\text { average }\end{array}$ & Average & $\begin{array}{l}\text { Below } \\
\text { average }\end{array}$ & Low \\
\hline Folk dance & 0 & 0 & 0 & 1 & 35 \\
\hline $\begin{array}{l}\text { Afterschool physical } \\
\text { activities }\end{array}$ & 1 & 0 & 1 & 3 & 59 \\
\hline $\begin{array}{l}\text { Without afterschool } \\
\text { activities }\end{array}$ & 0 & 0 & 0 & 0 & 17 \\
\hline
\end{tabular}

$P$ value -0.684 if $p \geq 0.05$, the difference between the groups is not statistically significant.

Fisher's direct test has been used $n=117$

Referring to the interview of the head of the Sports Laboratory and sports doctor Sandra Rozenštoka (Latvian social media, 2019), the tendency of children to obtain more "average", "below average" and "low" results in all three groups could be explained by the fact that children have excessive early specialization for certain physical activities, and insufficient time is devoted to general physical conditioning.

In the test, "sit-ups" folk dancers tend to get more "above average" and "high" results in 56\% of children, but "low," "below average" and "average" results in $44 \%$ of all children (table 5).

Table 5 Sit-ups, number in each group

\begin{tabular}{lccccc}
\hline $\begin{array}{l}\text { Classification of } \\
\text { children in groups }\end{array}$ & High & $\begin{array}{l}\text { Above } \\
\text { average }\end{array}$ & Average & $\begin{array}{l}\text { Below } \\
\text { average }\end{array}$ & \multicolumn{2}{l}{ Low } \\
\hline Folk dance & 14 & 6 & 8 & 4 & 4 \\
\hline Corrected balance & 1,1 & $-0,8$ & $-0,7$ & $-0,5$ & 1,2 \\
\hline $\begin{array}{l}\text { Afterschool physical } \\
\text { activities }\end{array}$ & 23 & 15 & 15 & 8 & 3 \\
\hline Corrected balance & 1,1 & 0,6 & $-0,8$ & $-0,4$ & $-1,0$ \\
\hline $\begin{array}{l}\text { Without afterschool } \\
\text { activities }\end{array}$ & 0 & 4 & 8 & 4 & 1 \\
\hline Corrected balance & -3 & 0,2 & 2,1 & 1,3 & $-0,2$ \\
\hline P
\end{tabular}

$P$ value - 0.041, if $p \leq 0,05$, the difference between the groups is statistically significant. Fisher's direct test has been used. Corrected balance $\geq \pm 2$ (significant deviation from the population as a whole) $n=117$

The differences in this test between children engaged in physical activity and children not engaged in afterschool physical activity could be explained by the fact that the various movements during physical activity requires involving of core muscles. 
Ciematnieks \&Gulbe, 2020. Impact of Folk Dance on Physical Conditioning of Younger School-Age Children

\section{Conclusions and discussion}

Analyzing the results of children's BMI and Eurofit tests, we observed increasing tendency for children body weight mismatch to height, and most motor tests tended to "average", "below average" or "low" results for all children. Based on the WHO Guidelines for Minimum Recommended Physical Activity (World Health Organization, 2011), where children should be active for 420 minutes (60 minutes a day) per week, both for children engaged in folk dancing and engaged in other afterschool activities a total amount of physical activity averages 179.55 minutes per week. Consequently, the weekly minimum recommended physical activity, is not achieved even with folk dance and other afterschool activities children are attending.

For children engaged in folk dance outside the school, BMI and Eurofit scores are largely equivalent to those for children engaged in other afterschool activities and also equivalent to children who do not engage in any physical activity. The only statistically significant difference is observed in the motor test "sit-ups", where children who do not engage in any activity tend to get "average", "below average" or "low" scores, whereas folk dancers and children engaged in afterschool activity tends to get "above average" and "high" results. Our research shows also, that 111 out of 117 subjects had a low level in shuttle run test. This drill requires many motor skills, not just one - speed in run between points; quickness to accelerate; strength, power and dexterity to stop, change running direction and make a first step. Low result in this test shows, that schoolchildren lack these motor skills no mater, they participate in any afterschool activity or not. This also can indicate on lack of physical activities in general that specific afterschool activities can not compensate. Children can master sport specific skills and develop specific functional body capabilities to execute special movements and achieve result in folk dance or other sport, but in general they lack overall fitness and their activities is not sufficient for healthy lifestyle.

The study shows that all of the child's out-of-school physical activity plays an important role in achieving the required amount of physical activity, in this case attending folk dance classes is not sufficient to achieve the required number of activities.

\section{References}

Adams, J., Veitch, J., \& Barnett, L. (2018). Physical Activity and Fundamental Motor Skill Performance of 5-10 Year Old Children in Three Different Playgrounds. International journal of environmental research and public health, 15(9), 1896.

Bāliṇa G. (2019). Nacionālā enciklopēdija. Deja Latvijā. Pieejams https://enciklopedija.lv/ skirklis/28801 
Cunningham, S.A., Datar, A., Narayan, K., \& Kramer, M.R. (2017). Entrenched obesity in childhood: findings from a national cohort study. Annals of epidemiology, 27(7), 435-441.

Yan, A.F., Cobley, S., Chan, C., Pappas, E., Nicholson, L.L., Ward, R.E., ... \& Wewege, M.A. (2018). The effectiveness of dance interventions on physical health outcomes compared to other forms of physical activity: a systematic review and meta-analysis. Sports Medicine, 48(4), 933-951.

Jansone, R., Fernāte, A., \& Bula-Biteniece, I. (2016). Sporta pedagogija vakar, šodien, rīt. Rīga, „Izdevniecība Raka”.

Kelli, L., Cain, K.A., Gavand, T.L., Conway, E., Peck, N.L., Bracy, E., Bonilla, P., \& Rincon,J. F.Sallis (2015). Physical Activity in Youth Dance Classes. Pediatrics, 135(6), 1066-1073.

Paes, S.T., Marins, J.C., \& Andreazzi, A E. (2015). Efeitos metabólicos do exercício físico na obesidade infantil: uma visão atual [Metabolic effects of exercise on childhood obesity: a current view]. Revista paulista de pediatria: orgao oficial da Sociedade de Pediatria de Sao Paulo, 33(1), 122-129.

Priedīte, I.S., Sauka, M., Kalniņa, L., \& Lāriņš, V. (2015). Vispārizglītojošo skolu skolēnu fiziskās sagatavotības izvērtēšana. Rīga.

Pudule, I., Velika, B., Grīnberga, D., Gobiņa, I., \& Villeruša, A. (2015). Latvijas skolēnu veselības paradumu pētījums 2013./2014. mācību gada aptaujas rezultāti un tendences. Slimību profilakses un kontroles centrs. SPKC.

Schroeder, K., Ratcliffe, S.J., Perez, A., Earley, D., Bowman, C., \& Lipman, T.H. (2017). Dance for Health: An Intergenerational Program to Increase Access to Physical Activity. Journal of pediatric nursing, 37, 29-34.

Spalva R. (2019). Nacionālā enciklopēdija. Tautas deja. Pieejams https://enciklopedija.lv/ skirklis/3950

Valsts izglītības satura centrs. (2019). XII Latvijas skolu jaunatnes dziesmu un deju svētku deju lielkoncerta ,, Saule vija zelta rotu” deju krājums. 1.dal̦a. Rīga.

Veselības ministrija. (2017). Informatīvais ziņojums par Eiropas Savienības veselības ministru 2017. gada 19. - 20. marta neformālajā sanāksmē izskatāmajiem jautājumiem. Pieejams http://www.vm.gov.lv/images/userfiles/Nozare/VMzino_130317_neform.pdf

World Health Organization. (2011). Physical activity and young people. Retrieved from https://www.who.int/dietphysicalactivity/factsheet_young_people/en/ 